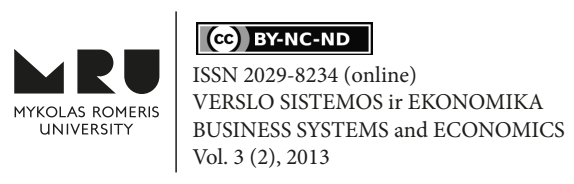

\title{
ŠALIES KONKURENCINGUMO POKYČIO OPTIMIZAVIMAS
}

\author{
Giedrè RAKAUSKIENE் \\ Vilniaus Gedimino technikos universitetas \\ Sauletekio al. 11, LT-10223, Vilnius, Lietuva \\ Elektroninis paštas: giedre.rakauskiene@vgtu.lt \\ Rima TAMOŠIŪNIENĖ \\ Mykolo Romerio universitetas \\ Ateities g. 20, LT-08303, Vilnius, Lietuva \\ Elektroninis paštas: rimtam@mruni.lt \\ doi:10.13165/VSE-13-3-2-03
}

Santrauka. Šiuo metu daugelis šalių ieško efektyvių sprendimų, kaip padidinti ir išlaikyti aukštą konkurencingumą. Ivairių konkurencingumo skatinimo priemonių igyvendinimui skiriami nemenki finansiniai ištekliai, kurių ribotumas kelia efektyvaus jų panaudojimo poreikį. Straipsnyje pristatomas optimalaus finansinių išteklių paskirstymo tarp šalies konkurencingumą lemiančių veiksnių uždavinio sprendimo modelis, kuriam rengti taikytas stochastinio programavimo metodas. Siekiant patikrinti siūlomo modelio praktini priimtinumą, atliekamas empirinis tyrimas Lietuvos atveju.

Reikšminiai žodžiai: šalies konkurencingumas, šalies konkurencingumo veiksniai, finansiniai ištekliai, optimizavimas, stochastinis programavimas.

JEL klasifikacija: O40, C61.

\section{Ivadas}

Šalies konkurencingumo tema per pastaruosius dešimtmečius tapo itin aktuali tarp šalių ieškančių sprendimų, kaip padidinti ir išlaikyti aukštą konkurencingumą, politikos atstovų. Tam tikslui šalyse steigiamos nacionalinio konkurencingumo tarybos, organizuojamos skirtingiems interesams atstovaujančių subjektų diskusijos, atliekami konkurencingumo vertinimai ir kuriamos strategijos. Siekiant igyvendinti šalių strategijose užsibrèžtus tikslus kuriamos ịvairios priemonès, kurioms igyvendinti skiriami nemenki finansiniai ištekliai. Finansiniai ištekliai, skiriami šalies konkurencingumo skatinimui, kaip ir bet kuriai kitai sričiai, yra riboti, todèl natūralus yra poreikis juos panaudoti kuo efektyviau ir pasiekti didžiausią galimą šalies konkurencingumo augimą. Tai kelia pagrịstų ir efektyvių sprendimų prièmimo būtinybę.

Šalių praktikos analizè (Tamošiūnienè ir Staskevičiūtè, 2011) atskleidžia, kad sprendimų, susijusių su šalies konkurencingumu, pagrindas yra konkurencingumo ver- 
tinimas. Priimant sprendimus yra atsižvelgiama į vertinimo rezultatus ir finansiniai ištekliai nukreipiami priemonems, skirtoms pagerinti blogiau įvertintų šalies konkurencingumo veiksnių būklę, kurti ir igyvendinti. Tačiau toks priimamų sprendimų pagrindas tiek dèl egzistuojančių metodinių problemų, tiek dèl priimamų sprendimų svarbumo lygio traktuotinas kaip per menkas. Priimant sprendimus, susijusius su šalies konkurencingumo skatinimui skirtu finansiniu išteklių panaudojimu, svarbu ịvertinti ne tik tai, kokia yra atskirų veiksnių būklè, bet ir kiek jie svarbūs bendram konkurencingumui bei kokị poveikị atskiram veiksniui turi finansiniai ištekliai. Žinant šiuos aspektus gali būti išspręstas optimalaus finansinių išteklių, skirtų šalies konkurencingumui, paskirstymo tarp šalies konkurencingumą lemiančių veiksnių uždavinys.

Straipsnyje pristatomas optimalaus finansinių išteklių paskirstymo tarp šalies konkurencingumą lemiančių veiksnių uždavinio sprendimo modelis, kuriam rengti panaudotas stochastinio programavimo metodas. Empirinių tyrimų atlikimui taikomi ekspertinio vertinimo metodai.

\section{Šalies konkurencingumą lemiantys veiksniai ir jų reikšmingumų nustatymas}

Mokslinejje literatūroje vis dar neprieinant vieno sutarimo dèl šalies konkurencingumo sampratos, nèra pateiktas ir vienas, visiems priimtinas šalies konkurencingumą lemiančių veiksnių rinkinys. Straipsnio autorès, atlikusios mokslinès ir praktinès literatūros analizę (Rakauskienė ir Tamošiūnienè, 2013), šalies konkurencingumą apibrěžia kaip jos gebejjimą pasiekti aukštą našumą ir užtikrinti visapusišką gyventojų gerovę. Siekiant identifikuoti šalies konkurencingumą lemiančius veiksnius, atitinkančius suformuluotą šalies konkurencingumo apibrèžimą, buvo atlikta veiksnių rinkinių, kuriuos pateikia pasaulyje pripažintos šalies konkurencingumo vertinimą atliekančios organizacijos, analizė. Gausus literatūros potencialas kiekvieno identifikuoto veiksnio atžvilgiu leido patvirtinti jų svarbą šalies konkurencingumui ir, atskleidžiant svarbiausius aspektus, apibrèžti turinị.

Šalies konkurencingumą lemiantys veiksniai ir jų turinys pateikti 1 lenteleje.

1 lentelè. Šalies konkurencingumą lemiantys veiksniai

\begin{tabular}{|c|c|}
\hline Veiksniai & Turinys \\
\hline $\begin{array}{l}\text { Institucinè } \\
\text { aplinka }\end{array}$ & $\begin{array}{l}\text { Teisiniai ir vyriausybės veiklos aspektai: teisinès ir reguliavimo sistemos efekty- } \\
\text { vumas ir kokybè, vyriausybės vykdomos veiklos skaidrumas irveiksmingumas }\end{array}$ \\
\hline $\begin{array}{l}\text { Makroekonominè } \\
\text { situacija }\end{array}$ & $\begin{array}{l}\text { Makroekonominị stabilumą nusakantys aspektai: fiskalinè ir monetarinè poli- } \\
\text { tika, viešieji finansai }\end{array}$ \\
\hline \begin{tabular}{|l|} 
Inžinerinė \\
infrastruktūra
\end{tabular} & $\begin{array}{l}\text { Transporto (kelių, geležinkelių, uostų, oro uostų) ir energijos perdavimo inf- } \\
\text { rastruktūros efektyvumas ir kokybė }\end{array}$ \\
\hline $\begin{array}{l}\text { Technologinè } \\
\text { infrastruktūra }\end{array}$ & $\begin{array}{l}\text { Informacinių technologijų ir telekomunikacijų prieinamumas ir naudojimas; } \\
\text { naujausių technologijų prieinamumas, diegimas }\end{array}$ \\
\hline \begin{tabular}{|l|} 
Mokslinè \\
infrastruktūra
\end{tabular} & $\begin{array}{l}\text { Inovaciju kūrimo pajègumai, mokslo institucijų kokybè, mokslo ir verslo ben- } \\
\text { dradarbiavimas, žmogiškuju mokslo ištekliu prieinamumas, našumas }\end{array}$ \\
\hline \begin{tabular}{|l} 
Švietimas \\
\end{tabular} & Pradinis ir aukštesnis švietimas, aukštasis mokslas ir darbuotoju mokymai \\
\hline Socialinè aplinka & $\begin{array}{l}\text { Sveikata ir sveikatos priežiūros kokybė, socialinè gerovè, ekologinè situacija, } \\
\text { atsinaujinančioji energija }\end{array}$ \\
\hline
\end{tabular}




\begin{tabular}{|l|l|}
\hline Produktų rinka & $\begin{array}{l}\text { Produktų rinkos efektyvumą nusakančios konkurencijos sąlygos: procedūros, } \\
\text { mokestinè ir teisinè bazė }\end{array}$ \\
\hline Darbo rinka & $\begin{array}{l}\text { Darbo rinkos efektyvumas ir lankstumas: teisinė ir reguliavimo sistema, rinkos } \\
\text { dalyvių santykiai, našumas, talentų naudojimas, lygios teisès }\end{array}$ \\
\hline Finansų rinka & $\begin{array}{l}\text { Bankų ir vertybinių popierių rinkos veiklos efektyvumas, prieinamumas ir pa- } \\
\text { tikimumas }\end{array}$ \\
\hline Verslo pažanga & Klasterių plètra, imonių atskaitomybè, valdymo praktika, kultūra, strategijos \\
\hline
\end{tabular}

Šaltinis: Rakauskienè ir Tamošiūnienè (2013)

Atsižvelgiant ị šiame straipsnyje pristatomo modelio idejją - optimaliai paskirstyti turimus finansinius išteklius tarp šalies konkurencingumą lemiančių veiksnių, iš 1 lentelèje pateikiamo rinkinio eliminuojamas makroekonominès situacijos veiksnys. Toks sprendimas priimamas atsižvelgiant $\underset{t}{\text { tai, }} \mathrm{kad}$ makroekonominès situacijos veiksnio turinị nusakantiems tokiems aspektams kaip fiskalinè politika, monetarinè politika ir viešieji finansai svarią ịtaką turi ne finansiniai ištekliai, o valdžios atstovų priimami sprendimai, jų vykdoma politika, atstovaujama ideologija. Nuo to, kaip veiksmingai dirbs, gebės kurti ir igyvendinti efektyvią ir patikimą politiką valdžios atstovai, kitaip tariant, nuo to, kokia bus institucinés aplinkos būkle, priklausys ir šalies makroekonominis stabilumas. Todèl makroekonominès situacijos veiksnys yra traktuojamas kaip rezultatas, kuris iš esmès priklauso nuo institucinès aplinkos veiksnio būklès.

Siekiant nustatyti, kiek vieno veiksnio svarba, lyginant su kitu veiksniu, yra didesnè ar mažesnè bendram šalies konkurencingumui, turi būti nustatyti šalies konkurencingumo veiksnių reikšmingumai.

Paprasčiausias žinomas veiksnių reikšmingumų nustatymo būdas yra vienodų visiems veiksniams reikšmingumų prièmimas. Toks sprendimas supaprastina šalies konkurencingumo vertinimą, tačiau tuo pat metu neatsižvelgimas ị skirtingą šalies konkurencingumą lemiančių veiksnių reikšmingumą sumenkina vertinimo tikslumą, dẻl ko kyla grèsmè priimamų sprendimų pagrịstumui. Atsižvelgiant ị tai atskiras šalies konkurencingumą lemiančių veiksnių reikšmingumų nustatymas traktuojamas kaip būtina sąlyga vertinimo tikslumui padidinti.

Gausus mokslinès literatūros reikšmingumų nustatymo tema potencialas (Saaty 2008; Zavadskas et al. 2001; Ginevičius ir Podvezko 2003, 2004, 2005, 2009; Ginevičius 2006; Podvezko 2009; Zavadskas ir Turskis 2011) suteikia reikšmingumų nustatymo metodo pasirinkimo laisvę. Išsami analizė leidžia identifikuoti du visus metodus vienijančius principus:

- reikšmingumų nustatymo pagrindas yra ekspertinis vertinimas;

- vertinimo logika: svarbiausias $j$-asis veiksnys turès didžiausią reikšmingumą $w_{j}$. Bendra reikšmingumų suma bus lygi vienetui:

$$
\sum_{j=1}^{n} w_{j}=1
$$

Kad ir koks reikšmingumų nustatymo metodas būtų pasirinktas, jo pagrindas bus ekspertinis vertinimas, kuris kaip vienintelè galimybe ịvertinti kiekybiškai neišmatuojamus reiškinius taikomas vis dažniau. Ir nors dèl jiems būdingo subjektyvumo ekspertiniai vertinimai nèra visiškai patikimi, mokslininkai (Maknickienè et al. 2011; Rutkauskas et al. 2011) sutinka, kad jie yra veiksnūs. 


\section{Šalies konkurencingumą lemiančių veiksnių būklès pokyčių dèl investuotų finansinių išteklių nustatymas}

Siekiant sudaryti šalies konkurencingumo pokyčio optimizavimo modelį svarbu žinoti, koki poveiki finansiniai ištekliai turi šalies konkurencingumą lemiantiems veiksniams. Atsižvelgiant ị tai, kad uždavinio sprendimui siūlomas naudoti originalus šalies konkurencingumą lemiančių veiksnių rinkinys, statistikos, kokią naudą generuoja ị kiekvieną jų investuojami finansiniai ištekliai, negali būti. Nesant galimybės kiekybiškai ịvertinti šalies konkurencingumą lemiančių veiksnių būklès pokyčius, siūlomas ekspertinio vertinimo metodas. Atliekant ekspertinị vertinimą ekspertai turi nurodyti numanomą kiekvieno šalies konkurencingumą lemiančio veiksnio būklès pagerèjimą (pokytị) dèl ị jị investuotos tam tikros konkurencingumui skirtos finansinių išteklių sumos.

Atliekant ekspertinị vertinimą susiduriama su neapibrěžtumo problema, nes šalies konkurencingumą lemiančių veiksnių būklès dẻl investuotų finansinių išteklių pokyčiai turi savybę igauti iš anksto vienareikšmiškai nenusakomas ir nuo atsitiktinių priežasčių priklausomas reikšmes. Todèl, kad ir kokie savo srities žinovai būtų vertinime dalyvausiantys ekspertai, konkrečiai, vienareikšmiškai ir užtikrintai pateikti vertinamo objekto įverčių jie negalès. Sprendžiant šią problemą A. V. Rutkauskas (2012) siūlo taikyti stochastiškai informatyvią ekspertizę. Taikant ši ekspertinio vertinimo modeli šalies konkurencingumą lemiančių veiksnių būklès dèl investuotų finansinių išteklių pokyčių ekspertiniai ịverčiai gali būti nusakomi galimybių tikimybių skirstinius apibūdinančiomis skaitinemis charakteristikomis.

Remiantis tikimybių teorija, šalies konkurencingumą lemiančių veiksnių būklès dèl investuotų finansinių išteklių pokyčiai laikomi atsitiktiniais dydžiais $\left(s_{j}\right)$. Daroma prielaida, kad atsitiktiniai dydžiai $s_{j}$ yra pasiskirstę pagal tolygujji dėsnị intervale $\left[s_{m j}, s_{d j}\right]$, kurio ribas nusako mažiausia $\left(s_{m j}\right)$ ir didžiausia $\left(s_{d j}\right)$ ekspertų $j$-ajam veiksniui suteiktos pokyčių reikšmès. Tada veiksnių pokyčių tankis bus toks:

$$
p\left(s_{j}\right)=\left\{\begin{array}{cl}
\frac{1}{s_{d j}-s_{m j}}, k a i \quad s_{m j} \leq s_{j} \leq s_{d j}, \\
0 & \text { kitur. }
\end{array}\right.
$$

Veiksnių pokyčių, pasiskirsčiusių pagal tolygụji skirstinị, skaitinės charakteristikos teorinis vidurkis $\left(E s_{j}\right)$ ir dispersija $\left(D s_{j}\right)$ - nustatomos pagal tokias formules:

$$
\begin{aligned}
& E s_{j}=\frac{s_{m j}+s_{d j}}{2}, \\
& D s_{j}=\frac{\left(s_{d j}-s_{m j}\right)^{2}}{12} .
\end{aligned}
$$

čia $s_{m j}$ - mažiausia $j$-ojo veiksnio pokyčio reikšmė; $s_{d j}$ - didžiausia $j$-ojo veiksnio pokyčio reikšmè. 


\section{Šalies konkurencingumo pokyčio optimizavimo modelis}

Žinant kiekvieno šalies konkurencingumą lemiančio veiksnio santykinį reikšmingumą ir veiksnių būklès pagerèjimo pokyčius dèl ị juos investuotos tam tikros finansinių išteklių sumos, gali būti sprendžiamas šalies konkurencingumo pokyčio optimizavimo uždavinys, kurio sprendimo rezultatai atsakys ị klausimą, kaip turimus finansinius išteklius paskirstyti tarp šalies konkurencingumą lemiančių veiksnių, kad būtų pasiektas optimalus šalies konkurencingumo augimo pokytis.

Atsižvelgiant ị tai, kad veiksnių pokyčiai yra atsitiktiniai dydžiai, turi būti sprendžiamas stochastinio programavimo uždavinys, kurio matematinis modelis atrodo taip:

$\max \Delta K$,

$P\left(\sum_{j=1}^{n} w_{j} s_{j} x_{j} \geq \Delta K\right) \geq 1-\alpha ;$

$\sum_{j=1}^{n} x_{j} \leq c$

$x_{j} \geq 0, j=1, \ldots, n$.

čia $w_{j}$ - j-ojo veiksnio reikšmingumas; $s_{j}$ - j-ojo veiksnio pokytis; $x_{j}$ - finansinių išteklių suma, skiriama $j$-ajam veiksniui (uždavinio nežinomasis); $c$ - šalies konkurencingumo skatinimui skirtų finansinių išteklių suma; $1-\alpha$ - pasikliovimo lygmuo (tikimybè); uždavinio nežinomasis $\Delta K$ - šalies konkurencingumo pokyčio $\sum_{j=1}^{n} w_{j} s_{j} x_{j}$ apatinè riba.

Nustatant uždavinio apribojimus [7-8] priimama, kad j-ajam veiksniui tenkančių finansinių išteklių suma $x_{j}$ negali būti neigiama ir bendra visiems veiksniams tenkanti finansinių išteklių suma negali viršyti šalies konkurencingumo skatinimui skiriamos sumos $c$. Sprendžiant optimizavimo uždavinį pagal ši modelị yra ieškomas toks nežinomųjų vektorius $X=\left(x_{1}, x_{2}, \ldots, x_{10}\right)$, kuriam esant šalies konkurencingumo pokytis $\sum_{j=1}^{n} w_{j} s_{j} x_{j}$ su tam tikru pasikliovimo lygmeniu 1 - $\alpha$ igis didžiausią reikšmę, t. y. bus optimalus.

Ekvivalentiškas stochastinio programavimo uždavinio matematiniam modeliui [5-8] yra toks netiesinio programavimo uždavinio matematinis modelis:

$$
\begin{aligned}
& \max \Delta K, \\
& \sum_{j=1}^{n} w_{j} E s_{j} x_{j}-u_{\alpha} z \geq \Delta K, \\
& z^{2}-\sum_{j=1}^{n} w_{j}^{2} D s_{j} x_{j}^{2}=0, \\
& \sum_{j=1}^{n} x_{j} \leq c ; \\
& x_{j} \geq 0, j=1, \ldots, n . \\
& z \geq 0,
\end{aligned}
$$

čia $E s_{j}$ - dydžio $s_{j}$ vidurkis; $u_{\alpha}$ - normaliojo skirstinio kritinè reikšmé; $z$ - papildomas kintamasis; $D s_{j}-$ dydžio $s_{j}$ dispersija. 


\section{Modelio empirinis patikrinimas Lietuvos atveju}

Siekiant patikrinti praktinị siūlomo šalies konkurencingumo pokyčio optimizavimo modelio priimtinumą atliktas empirinis tyrimas Lietuvos atveju. Ekspertinis vertinimas, kurio metu nustatyti Lietuvos konkurencingumo veiksnių reikšmingumai ir veiksnių pokyčiai, atliktas 2013 m. kovo-gegužès mèn. Vertinime dalyvavo šeši ekspertai, iš jų trys yra glaudžiai susiję su aukščiausio lygio strateginių sprendimų prièmimu, du vykdo mokslinius tyrimus tokiose mokslinių interesų srityse kaip ūkio ekonominis efektyvumas, ūkio plètra ir funkcionavimo patikimumas, finansų prognozavimas ir valdymas ir pan., vienas specializuojasi projektų rengimo ir igyvendinimo bei strateginio valdymo srityse. Ekspertai tyrimui pasirinkti atsižvelgiant ị jų aukštą kompetenciją ir žinių lygi.

Lietuvos konkurencingumą lemiančių veiksnių santykinių reikšmingumų nustatymui taikytas analitinės hierarchijos proceso (AHP) metodas. Šis metodas paremtas apibrežta matematinių matricų struktūra, kur atliekamas veiksnių lyginimas poriniu būdu. Vertinimui taikomi individualūs reikšmingumai gaunami panaudojant santykių skalę, ekspertiniu vertinimu nustatant vieno veiksnio dominavimą kito veiksnio atžvilgiu. Taikant AHP metodą reikšmingumai nustatomi ne tik remiantis ekspertiniu vertinimu, bet ir atliekamais matematiniais skaičiavimais, o tai sudaro prielaidas didesniam objektyvumui. Ekspertinis vertinimas atliekamas vadovaujantis šiam metodui ịprasta veiksmų seka (žr., pvz., Zavadskas et al., 2001; Podvezko, 2009).

Lietuvos konkurencingumą lemiančių veiksnių reikšmingumai pateikti 1 paveiksle.

1 pav. Lietuvos konkurencingumą lemiančiu veiksnių reikšmingumai, balai

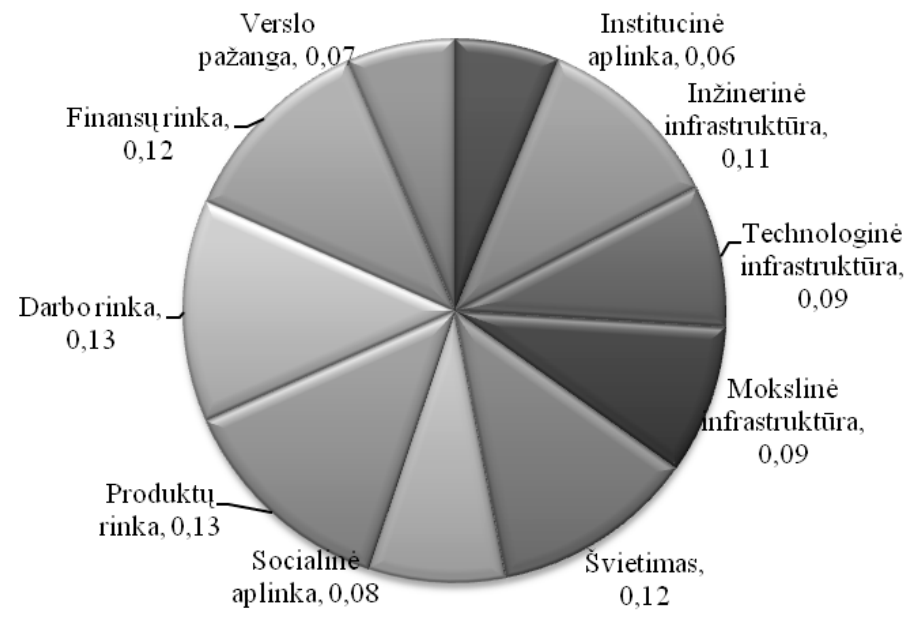

Šaltinis: sudaryta autorių

Iš 1 paveiksle pateikto grafiko matyti, kad šiuo metu Lietuvai, siekiančiai padidinti konkurencingumą, svarbiausias turi būti darbo ir produktų rinkų efektyvumas. Šiems veiksniams nustatytas vienodas $-0,13$ balo reikšmingumas. Kiti svarbūs veiksniai yra švietimas 
$(0,12)$, finansų rinka $(0,12)$ ir inžinerinè infrastruktūra $(0,11)$. Mažesnis reikšmingumas po 0,09 balo nustatytas technologinei ir mokslinei infrastruktūrai, o mažiausią reikšmę Lietuvos konkurencingumui turi verslo pažangos ir institucinès aplinkos veiksniai - jų reikšmingumai atitinkamai ịvertinti 0,07 ir 0,06 balo.

Siekiant nustatyti investicijų poveikį Lietuvos konkurencingumą lemiantiems veiksniams ekspertų buvo prašoma nurodyti numanomą kiekvieno Lietuvos konkurencingumą lemiančio veiksnio būklès pagerèjimą (pokytị) procentais dèl ị jị investuotų konkurencingumo skatinimui skirtų $100 \mathrm{mln}$. Lt. Pasiskirstymui esant tolygiajam veiksnių pokyčiai reikšmes igis intervale, kurio ribas nusako mažiausios ir didžiausios ekspertų pateiktos pokyčių reikšmès. Siekiant išspręsti Lietuvos konkurencingumo pokyčio optimizavimo uždavinị naudojantis [3] ir [4] formulèmis nustatomos veiksnių pokyčių skaitinės charakteristikos teorinis vidurkis ir dispersija (2 lentelè).

2 lentelè. Lietuvos konkurencingumą lemiančių veiksnių pokyčiai ir jų skaitinės charakteristikos

\begin{tabular}{|l|r|r|r|r|}
\hline \multicolumn{1}{|c|}{ Veiksniai } & \multicolumn{1}{c|}{$\begin{array}{c}\text { Mažiausia } \\
\text { reikšmė }\end{array}$} & \multicolumn{1}{c|}{$\begin{array}{c}\text { Didžiausia } \\
\text { reikšmé }\end{array}$} & \multicolumn{1}{c|}{ Vidurkis } & Dispersija \\
\hline Instituciné aplinka & 1 & 10 & 5,5 & 6,75 \\
\hline Inžineriné infrastruktūra & 1 & 6 & 3,5 & 2,08 \\
\hline Technologinè infrastruktūra & 2 & 8 & 5 & 3 \\
\hline Mokslinè infrastruktūra & 2 & 8 & 5 & 3 \\
\hline Švietimas & 1 & 8 & 4,5 & 4,08 \\
\hline Socialinè aplinka & 1 & 12 & 6,5 & 10,08 \\
\hline Produktu rinka & 1 & 10 & 5,5 & 6,75 \\
\hline Darbo rinka & 1 & 10 & 5,5 & 6,75 \\
\hline Finansų rinka & 1 & 8 & 4,5 & 4,08 \\
\hline Verslo pažanga & 1 & 12 & 6,5 & 10,08 \\
\hline
\end{tabular}

Šaltinis: sudaryta autorių

Vertinant investicijų poveikį Lietuvos konkurencingumą lemiantiems veiksniams manoma, kad investavus $100 \mathrm{mln}$. Lt didžiausias pokytis būtų jaučiamas verslo pažangos ir socialinès aplinkos veiksnių būklès pagerèjimo atžvilgiu - 12 proc., o mažiausias inžinerinès infrastruktūros - 6 proc. Kitų sričių būklès pagerèjimo didžiausias pokytis: produktų, darbo rinkos ir institucinès aplinkos - 10 proc., finansų rinkos, technologinès ir mokslo infrastruktūros, švietimo - 8 proc. Mažiausias veiksnių būklès pagerejjimo pokytis beveik visiems veiksniams siekia 1 proc., išskyrus technologinę ir mokslinę infrastruktūrą, kurioms mažiausio pokyčio riba yra kiek aukštesnè -2 proc.

Nustačius Lietuvos konkurencingumą lemiančių veiksnių santykinius reikšmingumus ir veiksnių pokyčius toliau buvo sprendžiamas stochastinio programavimo uždavinys. Priimta, kad bendra Lietuvos konkurencingumui skiriama suma sudaro 10 piniginių vienetų (1 piniginis vienetas atitinka $100 \mathrm{mln}$. Lt). Gauti uždavinio sprendiniai pateikti 3 lenteleje. 
3 lentelè. Lietuvos konkurencingumo pokyčio optimizavimo sprendiniai

\begin{tabular}{|c|c|c|c|c|c|c|c|c|c|c|c|}
\hline $1-\alpha$ & $\begin{array}{c}\text { Inst. } \\
\text { apl. } \\
x_{1} \\
\end{array}$ & $\begin{array}{c}\text { Inž. } \\
\text { infr. } \\
x_{2} \\
\end{array}$ & \begin{tabular}{|c|} 
Techn. \\
infr. \\
$x_{3}$ \\
\end{tabular} & \begin{tabular}{|c|} 
Moksl. \\
infr. \\
$x_{4}$ \\
\end{tabular} & $\begin{array}{c}\text { Šviet. } \\
x_{5} \\
\end{array}$ & $\begin{array}{c}\text { Soc. } \\
\text { apl. } \\
x_{6} \\
\end{array}$ & $\begin{array}{c}\text { Prod. } \\
\text { rinka } \\
x_{7} \\
\end{array}$ & $\begin{array}{c}\text { Darbo } \\
\text { rinka } \\
x_{8} \\
\end{array}$ & $\begin{array}{c}\text { Fin. } \\
\text { rinka } \\
x_{9} \\
\end{array}$ & $\begin{array}{c}\text { Verslo } \\
\text { paž. } \\
x_{10} \\
\end{array}$ & $\Delta K$ \\
\hline 0,6 & & & & & & & 5,01 & 4,99 & & & 0,067 \\
\hline 0,78 & & & & & 0,28 & & 4,86 & 4,86 & & & 0,055 \\
\hline 0,8 & & & & & 0,83 & 0,34 & 4,15 & 4,16 & 0,52 & & 0,053 \\
\hline 0,85 & & & & & 1,44 & 1,01 & 3,14 & 3,14 & 1,27 & & 0,050 \\
\hline 0,9 & & & & & 1,75 & 1,35 & 2,63 & 2,63 & 1,64 & & 0,046 \\
\hline 0,93 & & & & 0,12 & 1,86 & 1,49 & 2,37 & 2,38 & 1,78 & & 0,043 \\
\hline 0,95 & & & 0,62 & 0,76 & 1,64 & 1,33 & 1,90 & 1,90 & 1,59 & 0,27 & 0,041 \\
\hline \begin{tabular}{|l|}
0,97 \\
\end{tabular} & & 0,28 & 1,05 & 1,14 & 1,43 & 1,17 & 1,52 & 1,52 & 1,40 & 0,50 & 0,038 \\
\hline 0,99 & & 0,73 & 1,38 & 1,43 & 1,22 & 1,02 & 1,17 & 1,17 & 1,21 & 0,68 & 0,034 \\
\hline
\end{tabular}

Šaltinis: sudaryta autorių

Uždavinio sprendiniai rodo piniginių vienetų skaičių, skiriamą kiekvienam Lietuvos konkurencingumą lemiančiam veiksniui pasirinkus tam tikrą tikimybę. Tikslo funkcijos reikšmẻ parodo optimalų Lietuvos konkurencingumo pokytị, kuris būtų pasiektas su atitinkama tikimybe.

Pateiktas finansinių išteklių paskirstymo planas už sprendimų prièmimą atsakingiems subjektams sudaro galimybes rinktis tarp skirtingų variantų. Pasirinkus pasikliovimo lygmeni (tikimybę) 0,6 optimalus Lietuvos konkurencingumo pokytis bus pasiektas visus finansinius išteklius po lygiai (po 5 piniginius vnt.) paskirsčius produktų rinkos ir darbo rinkos veiksniams. Didinant pasikliovimo lygmenį ir pasirinkus, pvz., 0,8 finansinius išteklius, siekiant optimalaus Lietuvos konkurencingumo pokyčio, derètų paskirstyti tarp tokių penkių veiksnių kaip švietimas, socialinė aplinka, produktų rinka, darbo rinka ir finansų rinka, daugiausia (po apytiksliai 4 piniginius vnt.) skiriant produktų ir darbo rinkoms. Pasirinkus didžiausią pasikliovimo lygmenị $(0,99)$ finansinius išteklius beveik vienodomis proporcijomis tikslinga paskirstyti tarp visų Lietuvos konkurencingumą lemiančių veiksnių, išskyrus institucinès aplinkos veiksnị.

Priimant sprendimą, kurị finansinių išteklių paskirstymo planą pasirinkti, tikslinga ịvertinti tai, kad didelis Lietuvos konkurencingumo pokytis yra mažai tikètinas. Visus finansinius išteklius nukreipus produktų ir darbo rinkų efektyvumui užtikrinti sẻkmès atveju Lietuvos konkurencingumas padidetų ne mažiau kaip 0,067 balo. Tačiau tikimybè, kad nepasiseks, taip pat nemaža - 0,4. Turimus finansinius išteklius paskirsčius proporcingai tarp visų Lietuvos konkurencingumo veiksnių (išskyrus institucinès aplinkos veiksnį) optimalus konkurencingumo pokytis bus dvigubai mažesnis, tačiau beveik garantuotas.

\section{Išvados}

Šalies konkurencingumo skatinimui skiriami nemenki finansiniai ištekliai atskleidžia efektyvaus jų panaudojimo poreikį. Toks poreikis suponuoja optimalaus finansinių išteklių paskirstymo tarp šalies konkurencingumą lemiančių veiksnių uždavinio išsprendimo būtinybę. 
Uždavinio sprendimui sudarytas šalies konkurencingumo pokyčio optimizavimo modelis, ị kurio tikslo funkciją įtraukti tokie parametrai, kaip šalies konkurencingumo veiksnių santykiniai reikšmingumai ir šalies konkurencingumo veiksnių būklès pokyčiai dèl investuotų finansinių išteklių. Kadangi pastarieji parametrai dèl jiems būdingo neapibrèžtumo priskirtini tolydiesiems atsitiktiniams dydžiams, optimizavimo uždavinys sprendžiamas stochastinio programavimo metodu.

Šalies konkurencingumą lemiančių veiksnių santykinių reikšmingumų ir šalies konkurencingumo veiksnių būklès pokyčių dèl investuotų finansinių išteklių nustatymui siūlomi taikyti ekspertinio vertinimo metodai.

Siekiant patikrinti šalies konkurencingumo pokyčio optimizavimo modelio praktinị priimtinumą atliktas empirinis tyrimas Lietuvos atveju. Gauti tyrimo rezultatai leidžia konstatuoti modelio tinkamumą priimant sprendimus, susijusius su šalies konkurencingumo skatinimui skirtų finansinių išteklių efektyviu panaudojimu.

\section{Literatūra}

Ginevičius, R. (2006). Daugiakriterinio vertinimo rodiklių svorių nustatymas, remiantis jų tarpusavio sąveika. Verslas: teorija ir praktika. 7(1): 3-13.

Ginevičius, R., and Podvezko, V. (2009). Evaluating the changes in economic and social development of Lithuanian countries by multiple criteria methods. Technological and Economic Development of Economy. 15(3): 418-436.

Ginevičius, R., ir Podvezko, V. (2003). Hierarchiškai struktūrizuotų rodiklių reikšmingumo kompleksinis įvertinimas. Verslas: teorija ir praktika. 4(3): 111-116.

Ginevičius, R., and Podvezko, V. (2004). Quantitative Assessing the Accuracy of Expert Methods. Inžinerine ekonomika. 5(40): 7-12.

Ginevičius, R., and Podvezko, V. (2005). Objective and Subjective Approaches in Determining the Criterion Weights in Multicriteria Models. Transport and Telecommunication. 6(1): 133-137.

Maknickiene, N., Rutkauskas, A. V., ir Maknickas, A. (2011). Investigation of financial market prediction by recurrent neural network. Innovative Technologies for Science, Business and Education. 2(11): 3-8.

Podvezko, V. (2009). Application of AHP technique. Business Economics and management. 10(2): 181-189.

Rakauskienè, G., ir Tamošiūnienè, R. (2013). Šalies konkurencingumą lemiantys veiksniai. Verslas: teorija ir praktika. 14(1): 177-187.

Rutkauskas, A. V. (2012). Stochastically informed expertise as natural step for experts systems network development. Conference Proceedings of the 2nd International Scientific Conference „Whither our Economies - 2012". Vilnius: Mykolas Romeris University, 46-53.

Rutkauskas, A. V., Stasytyte, V., ir Maknickienė, N. (2011). Entrepreneurship portfolio construction and management. Proceedings of the Annual International Conference on Innovation and Entrepreneuship (IE 2011) (57-56). Singapore: Global Science and Technology Forum (GSTF).

Saaty, T. L. (2008). The Analytic Hierarchy and Analytic Network Measurement Processes: Applications to Decisions under Risk. European Journal of Pure and Applied Mathematics. 1(1): 122-196.

Tamošiūnienè, R., ir Staskevičiūte, G. (2011). Nacionalinio konkurencingumo politikos formavimo praktika. Socialiniu mokslų studijos. 3(2): 487-503.

Zavadskas, E. K., ir Turskis, Z. (2011). Multiple Criteria Decision Making (MCDM) Methods in Economics: an Overview. Technological and Economic Development of Economy 17(2): 397-427.

Zavadskas, E. K., Kaklauskas, A., ir Banaitienè, N. (2001). Pastato gyvavimo proceso daugiakriterine analize. Vilnius: Technika. 


\title{
THE OPTIMIZATION OF COUNTRY'S COMPETITIVENESS CHANGE
}

\author{
Giedrè RAKAUSKIENE \\ Vilnius Gediminas Technical University, Lithuania \\ Rima TAMOŠIŪNIENĖ \\ Mykolas Romeris University, Lithuania
}

\begin{abstract}
Currently, different countries are seeking for effective decisions how to increase and maintain high national competitiveness. Considerable financial resources are allocated for implementation of means created to promote competitiveness. The limitation of financial resources requires effective use solutions. This paper presents the model to solve the task of optimal financial resources allocation among the competitiveness factors. The model is prepared using stochastic programming approach. In order to verify practical acceptability of the suggested model, the empirical research is performed on Lithuania's case.
\end{abstract}

Keywords: country's competitiveness, factors of country's competitiveness, financial resources, optimization, stochastic programming 